Zeszyty Naukowe Szkoły Głównej Gospodarstwa Wiejskiego w Warszawie Problemy Rolnictwa Światowego tom 17 (XXXII), zeszyt 1, 2017: 125-141

DOI: $10.22630 /$ PRS.2017.17.1.12

Agnieszka Obiedzińska ${ }^{1}$

Instytut Ekonomiki Rolnictwa i Gospodarki Żywnościowej - Państwowy

Instytut Badawczy w Warszawie

\title{
Wpływ strat i marnotrawstwa żywności na bezpieczeństwo żywnościowe
}

\section{Impact of Food Losses and Waste on Food Security}

\begin{abstract}
Synopsis. Powstające straty i marnotrawstwo żywności (SMŻ) są wynikiem nieefektywnego funkcjonowania systemów żywnościowych. W zależności od wolumenu czy regionu, w którym występują generują one skutki ekonomiczne, społeczne, środowiskowe oraz zdrowotne. W pracy przeprowadzono analize dostępnej polskiej i zagranicznej literatury naukowej dotyczącej problematyki bezpieczeństwa żywnościowego oraz strat $\mathrm{i}$ marnotrawstwa żywności. Straty $\mathrm{i}$ marnotrawstwo żywności generują wiele negatywnych skutków, które mogą bezpośrednio bądź pośrednio wpływać na 4 filary bezpieczeństwa żywnościowego: dostępność żywności, dostęp do żywności, wykorzystanie żywności oraz stabilność dostepności i dostepu do żywności w czasie. Wiele działań jest podejmowanych $\mathrm{w}$ celu prewencji bądź zminimalizowania generowanych strat $\mathrm{i}$ marnotrawstwa. Z drugiej strony już powstałe straty czy zmarnowana żywność może być wykorzystana m.in. do redystrybucji bądź powtórnego wykorzystania żywności bądź jej składników, co może przyczyniać się do zapewnienia bezpieczeństwa żywnościowego.
\end{abstract}

Słowa kluczowe: straty i marnotrawstwo żywności, bezpieczeństwo żywnościowe

\begin{abstract}
Occurring food losses and waste (FLW) are a result of ineffective functioning of food systems. Depending on the volume or region in which they occur they generate economic, social, environmental and health impacts. This paper analyzes the available polish and foreign scientific literature on the issue of food security and food losses and waste. Food losses and waste generate a lot of negative effects, which may directly or indirectly affect the four pillars of food security: food availability, access to food, food utilization and stability. Many activities are undertaken in order to prevent or minimize generated food losses and waste. On the other hand already created losses or waste can be used for example by redistributing or reusing food or its components, which may contribute to ensure food security.
\end{abstract}

Key words: food losses and waste, food security

\section{Wstęp}

Nasilające się na przełomie XX i XXI wieku zjawiska takie jak globalizacja handlu żywności, komercjalizacja systemów żywnościowych, postępujący proces urbanizacji czy zmiany nawyków żywieniowych ludności świata sprawiły, że zmienił się sposób produkcji, przetwórstwa, dystrybucji i konsumpcji żywności wpływając m.in. na generowanie strat i marnotrawstwa żywności (Parfitt i in., 2010). Straty i marnotrawstwo żywności (SMŻ) są wynikiem czynników gospodarczych, technicznych, społecznych i kulturowych, które oddziałują na funkcjonowanie systemów żywnościowych (HLPE, 2014). Mogą one być

\footnotetext{
${ }^{1}$ dr inż., Zakład Ogólnej Ekonomiki IERiGŻ-PIB, ul. Świętokrzyska 20, 00-002 Warszawa,
} e-mail: agnieszka.obiedzinska@ierigz.waw.pl 


\section{A. Obiedzińska}

rozpatrywane pod kątem utraty możliwości wyżywienia ludności tym samym wpływając na zapewnienie im bezpieczeństwa żywnościowego. Dodatkowo w ciagu ostatnich dziesięcioleci podejście człowieka względem środowiska i wykorzystania ograniczonych zasobów naturalnych diametralnie się zmieniło. SMŻ reprezentują m.in. straty nakładów pracy, wody, ziemi, surowców i energii oraz produkcję niekorzystnych dla środowiska gazów cieplarnianych. Coraz częściej podnoszone są debaty, aby ograniczyć powstawanie strat w całym łańcuchu rolno-żywnościowym oraz marnotrawstwa, w szczególności na etapie konsumpcji (Parfitt i in., 2010; Searchinger i in., 2013; Lipinski i in., 2013). Z uwagi na wzrastającą liczbę ludności, coraz bardziej globalny charakter systemów żywnościowych (w tym produkcji rolnej), towarzysząca produkcji żywności presji na środowisko oraz ilość powstających strat i marnotrawstwa żywności wzdłuż całego łańcucha rolno-żywnościowego może pojawić się pytanie: jaki wpływ mają zachodzące procesy na bezpieczeństwo żywnościowe? Próba odpowiedzi na to pytanie jest podejmowana w krajach rozwiniętych - zachodnich i coraz częściej także na płaszczyźnie krajowej. Dlatego też, celem artykułu było przeanalizowanie wpływu powstających strat i marnotrawstwa żywności na zapewnienie bezpieczeństwa żywnościowego.

\section{Materiał i metodyka badań}

W pracy przeprowadzono analizę dostępnej polskiej i zagranicznej literatury naukowej dotyczącej problematyki bezpieczeństwa żywnościowego oraz strat i marnotrawstwa żywności. Kryterium doboru literatury do rozważań był obecny i potencjalny wpływ strat i marnotrawstwa żywności na bezpieczeństwo żywnościowe uwzględniając jego cztery filary: dostęp do żywności, dostępność żywności, wykorzystanie żywności i stabilność dostępu do żywności i dostępności żywności. Wnioski zostały opracowane w oparciu o metodę indukcji.

\section{Bezpieczeństwo żywnościowe i jego cztery filary}

Na zapewnienie bezpieczeństwa żywnościowego ${ }^{2}$ wpływ ma wiele czynników, które oddziałują między sobą (Godfray i in., 2010). Przy prognozowanym do 2050 roku wzroście liczby ludności świata do 9 mld osób, wyzwaniem dla funkcjonujących systemów żywnościowych jest i będzie zapewnienie wystarczajacej, bezpiecznej $i$ odżywczej żywności, zaspokajajacej ich potrzeby żywieniowe $i$ preferencje dla prowadzenia aktywnego i zdrowego życia (FAO, IFAD, WFP, 2015 s.53). Problem niedożywienia ${ }^{3}$, który jest przejawem braku zapewnienia bezpieczeństwa żywnościowego wciąż jest aktualny. Obecnie mówi się o potrójnym obciążeniu spowodowanym przez niedożywienie (PinstrupAndersen, 2007; Capacci i in., 2013). Pierwsze z nich - chroniczne niedożywienie czyli niedożywienie ilościowe (undernourishment, chronic hunger) wynika z niemożności

\footnotetext{
${ }^{2}$ Bezpieczeństwo żywnościowe to sytuacja, w której ,wszyscy ludzie, przez cały czas, maja fizyczny, społeczny $i$ ekonomiczny dostęp do wystarczajacej, bezpiecznej i odżywczej żywności, zaspokajajacej ich potrzeby żywieniowe i preferencje dla prowadzenia aktywnego i zdrowego życia" (FAO, 2009).

${ }^{3}$ Niedożywienie (malnutrition) brak równowagi występująy na poziomie komórkowym między zapotrzebowaniem na składniki pokarmowe i energię a podaża, której zaspokojenie pozwala na wzrost, podtrzymywanie funkcji życiowych oraz petnienie określonych funkcji (WHO, 2016).
} 
zapewnienia odpowiedniej ilości kalorii (energii z pożywienia), tak, aby organizm mógł sprawnie funkcjonować i prawidłowo się rozwijać. Rocznie ponad 9 mln osób umiera $\mathrm{z}$ powodu głodu, a ponad $795 \mathrm{mln}$ osób cierpi z powodu niedożywienia ilościowego ${ }^{4}$ [FAO, IFAD, WFP 2015]. Ponad $98 \%$ tych osób zamieszkuje tereny krajów rozwijających się, głównie krajów Afryki i Azji. Pomimo tego, że w przeciagu ostatnich 25 lat liczba osób niedożywionych na świecie spadła o $21,4 \%$, to w regionie Afryki liczba ta istotnie wzrosła o 28\% (50,8 mln osób; tab. 1).

Tabela 1. Niedożywienie na świecie

Table 1. Undernourishment around the world

\begin{tabular}{c|ccccc}
\hline & \multicolumn{2}{|c}{ Liczba osób niedożywionych (mln) } & \multicolumn{2}{c}{$\begin{array}{c}\text { Udział osób niedożywionych } \\
\text { w całkowitej populacji świata (\%) }\end{array}$} \\
& $1990-92$ & $2014-16$ & $\begin{array}{c}1990-92 / \\
2014-16\end{array}$ & $1990-92$ & $2014-16$ \\
\hline Świat & 1010,6 & 794,6 & $-21,4 \%$ & 18,6 & 10,9 \\
Kraje rozwinięte & 20,0 & 14,7 & $-26,5 \%$ & 2,0 & 1,8 \\
Kraje rozwijające się & 990,7 & 779,9 & $-21,3 \%$ & 23,3 & 12,9 \\
Afryka & 181,7 & 232,5 & $+28,0 \%$ & 27,6 & 12,1 \\
Azja & 741,9 & 511,7 & $-31,0 \%$ & 23,6 & 5,5 \\
Ameryka Łacińska & 66,1 & 34,3 & $-48,1 \%$ & 14,7 & 14,2 \\
i Karaiby & 1,0 & 1,4 & $+40,0 \%$ & 15,7 & \\
Oceania & & & & & 20 \\
\hline
\end{tabular}

Źródło: ppracowano na podstawie FAO, IFAD, WFP (2015).

Ponadto na świecie ponad 2 mld osób odczuwa skutki związane z niedożywieniem jakościowym (undernutrition, micronutrient deficiency), czyli pomimo dostarczenia organizmowi odpowiedniej ilości kalorii, nie dostarcza odpowiedniej ilości makroskładników (białek, węglowodanów bądź tłuszczy) i/lub mikroskładników (m.in. składników mineralnych i witamin), które wpływają na sprawne funkcjonowanie organizmu (Godfray i in., 2010; IFPRI, 2016). Zarówno niedożywienie pod względem ilościowym jak i jakościowym może prowadzić do wystąpienia wielu chorób m.in. anemii przy deficycie żelaza, „kurzej ślepoty” przy deficycie witaminy A, marasmus i kwashiorkor przy deficycie białkowo-energetycznym (MacPhail, 2012; Thurnham, 2012; Truswell, 2012; Włodarek i in., 2014). Obok niedożywienia ilościowego i jakościowego wymienia się niedożywienie związane $\mathrm{z}$ występowaniem nadwagi i otyłości oraz innych chorób dietozależnych związanych z nadkonsumpcją żywności (overnutrition) (Pinstrup-Andersen, 2007; Capacci i in., 2013). Z danych udostępnianych przez Światową Organizację Zdrowia (WHO) wynika, że na świecie ponad 2 mld osób dorosłych choruje z powodu nadwagi i otyłości, a $41 \mathrm{mln}$ dzieci poniżej 5. roku życia ma nadwagę (IFPRI, 2016). Szacując całkowite obciążenie wywoływanym przez niedożywienie trzeba pamiętać, że liczba osób dotkniętych różnymi rodzajami niedożywienia nie może być zsumowana, ponieważ jedna osoba może cierpieć jednocześnie np. $\mathrm{z}$ powodu niedożywienia ilościowego $\mathrm{i}$

4 Według metodologii FAO dotyczącej szacowania liczby osób niedożywionych (głodujących) na świecie wykorzystuje się liczbę osób, które cierpią z powodu niedożywienia pod względem energetycznym czyli liczby dostarczanych kalorii (FAO, IFAD, WFP, 2015). 


\section{A. Obiedzińska}

jakościowego. Każdy wymiar niedożywienia dotyczy zarówno krajów rozwijających się jak i rozwiniętych, jednakże może dotyczyć różnych regionów w innym stopniu. Jednakże wszystkie wynikające obciążenia są skutkiem braku zapewnienia bezpieczeństwa żywnościowego. Przez ostatnich 60 lat zarówno zakres jak i podejście do bezpieczeństwa żywnościowego się zmieniało (CFS, 2012; Marzęda-Młynarska, 2014). Na początku bezpieczeństwo żywnościowe było synonimem zapewnieniu odpowiedniej podaży podstawowych produktów żywnościowych na poziomie narodowym czy globalnym. Obecnie, aby bezpieczeństwo żywnościowe było zapewnione, każdy człowiek, przez cały czas musi mieć zapewniony fizyczny, społeczny i ekonomiczny dostęp do wystarczajacej, bezpiecznej $i$ odżywczej żywności (FAO, IFAD, WFP, 2015). Bezpieczeństwo to powinno być zapewnione na każdym poziomie: globalnym, krajowym, gospodarstwa domowego oraz jednostki (Marzęda-Młynarska, 2014). Na podstawie definicji bezpieczeństwa żywnościowego Organizacja Narodów Zjednoczonych ds. Wyżywienia i Rolnictwa (FAO) identyfikuje 4 filary bezpieczeństwa żywnościowego, czyli dostępność żywności, dostęp do żywności, wykorzystanie żywności oraz stabilność, które muszą być jednocześnie spełnione aby mówić o zapewnieniu bezpieczeństwa żywnościowego (tab. 2) (FAO, 2008).

Tabela 2. Cztery filary bezpieczeństwa żywnościowego

Table 2. Four pillars of food security

\begin{tabular}{l|l}
\hline \multicolumn{1}{c}{ Filary } & \multicolumn{1}{c}{ Opis } \\
\hline $\begin{array}{l}\text { dostępność } \\
\text { żywności }\end{array}$ & $\begin{array}{l}\text { Zapewnienie odpowiedniej ilości żywności, która będzie zaspokajać potrzeby żywieniowe } \\
\text { każdej osoby poprzez m.in. krajową produkcję żywności (w tym produkcję rolną), import } \\
\text { żywności oraz prowadzenie zapasów surowców rolnych bądź żywności i pomoc } \\
\text { żywnościową. Odpowiada stronie podażowej bezpieczeństwa żywnościowego. }\end{array}$ \\
$\begin{array}{l}\text { dostęp do } \\
\text { żywności }\end{array}$ & $\begin{array}{l}\text { Dostęp (fizyczny i ekonomiczny) jest zapewniony, gdy wszystkie osoby bądź gospodarstwa } \\
\text { domowe dysponują wystarczającymi środkami m.in. finansowymi, aby pozyskać } \\
\text { odpowiednią ilość żywności aby móc prowadzić odżywczą dietę. Na dostęp do żywności } \\
\text { wpływ ma m.in. dochód ludności, siła nabywcza czy infrastruktura systemów } \\
\text { żywnościowych np. transport. } \\
\text { Wykorzystanie żywności uwarunkowane jest zapewnieniem jakości zdrowotnej żywności } \\
\text { wykorzystanie } \\
\text { żywności } \\
\text { przechowywapewnienia bezpieczeństwa żywności (np. przestrzeganie reguł w zakresie } \\
\text { prowadzenie zróżnicowanej diety charakteryzującej się wysoką jakością i różnorodnością } \\
\text { produktów) tak aby spełnić potrzeby biologiczne i społeczne (kulturowe) każdej osoby. } \\
\text { Na stabilność dostępności i dostępu do żywności w czasie wpływa m.in. sezonowość } \\
\text { produktów, czynniki klimatyczne (susza, powódź), nieurodzaj upraw czy wahania cen. Za } \\
\text { brak bezpieczeństwa żywnościowego może być uznany nawet okresowy niewystarczający } \\
\text { dostęp do żywności, który wpływa na pogorszenie się stanu odżywienia organizmu. } \\
\text { Stabilność wpływa na funkcjonowanie pozostałych filarów. }\end{array}$ \\
stabilność
\end{tabular}

Źródło: opracowano na podstawie Gross i in. (2000), FAO (2008), Marzęda-Młynarska (2014).

Prognozuje się, że do roku 2050 zapewnienie bezpieczeństwa żywnościowego będzie wymagało wzrostu światowej produkcji żywności o 60-70\% (Alexandratos, Bruinsma, 2012). Wiele krajów rozwijających się będzie musiało podwoić produkcję żywności, aby wyżywić szybko zwiększające się populacje. Będzie to także wymagało uwzględnienia wielu czynników takich jak np. zmieniające się nawyki żywieniowe ludności, zmiany demograficzne wynikające ze starzejącego się społeczeństwa czy postępujących procesów urbanizacyjnych. Ponadto, czynniki ekonomiczne takie jak wzrastający dochód, wpływają na występowanie zmian we wzorcach żywieniowych, co prowadzi do wzrostu popytu na 
żywność i produkty rolne, które charakteryzują się największym śladem ekologicznym (np. mięso i produkty mięsne) (European Commission, 2009; Godfray i in., 2010). Dodatkowo zwiększająca się konkurencja o wykorzystanie zasobów naturalnych (ziemi, wody, energii) będzie miała coraz większy wpływ na produkcję żywności. Negatywne oddziaływanie tejże produkcji na te zasoby i środowisko, w tym bioróżnorodność zwierzęcą i roślinną, będzie w coraz większym stopniu warunkować funkcjonowanie systemów żywnościowych w przyszłości (Godfray i in., 2010). Niewątpliwie jednym z czynników wpływającym na zapewnienie bezpieczeństwa żywnościowego są generowane straty i marnotrawstwo żywności w całym łańcuchu rolno-żywnościowym, które wynikają z nieefektywnego i nierównego funkcjonowania systemów żywnościowych (HLPE, 2014).

\section{Straty i marnotrawstwo żywności}

FAO definiuje straty i marnotrawstwo żywności jako „wszelkie produkty przetworzone, częściowo przetworzone lub nieprzetworzone, przeznaczone do spożycia przez ludzi lub których spożycia przez ludzi można się spodziewać, a takíe takie, które pomimo ich wytworzenia, nie zostaty przez nich spożyte" (FAO, 2014). Odnoszą się one do jadalnych części żywności pochodzenia zwierzęcego i roślinnego, które powstają na wszystkich etapach łańcucha rolno-żywnościowego (BCFN, 2012; HLPE, 2014; Tielens, Candel, 2014; Gustavsson i in., 2011). Powyższa definicja jest najbardziej znaną jednak wciąż istnieje ponad 100 innych, które uwzględniają takie aspekty jak aspekt fizjologiczny, aspekt kulturowy (dla jednych społeczeństw coś, co nie jest przydatne do spożycia dla innych może być jadalne, np.: mięso końskie czy owady), aspekt technologiczny (np. wykorzystanie części jadalnych na cele nieżywnościowe - pasze bądź produkcja biopaliw), aspekt ekonomiczny (np. czy dany element żywności może generować wartość dodaną), aspekt zdrowotny (np. nadmierna konsumpcja żywności, czyli spożycie żywności ponad zalecane spożycie, które w konsekwencji prowadzi do wystapienia chorób dietozależnych, m.in. nadwagi i otyłości) (Rutten, 2013; Lipinski i in., 2013; HLPE, 2014; EIU, 2104). Odpowiednie zdefiniowanie strat i marnotrawstwa żywności determinuje poprawne szacowanie skali ich występowania. Według FAO, ponad 1,3 mld ton czyli $1 / 3$ produkowanej globalnie żywności ulega stracie bądź jest marnotrawiona (Gustavsson i in., 2011). Wielkość czy też udział powstających SMŻ oraz czynniki na nie wpływające zależą od typu żywności, poziomu rozwoju danego regionu czy kraju, który jest brany pod uwage oraz od etapu łańcucha rolno-żywnościowego, w którym powstają SMŻ (rys. 1). Z przeliczenia podanych przez FAO danych powstałych SMŻ na jednego mieszkańca wynika, że rocznie mieszkaniec krajów rozwiniętych jak np. regionu Ameryki Północnej i Oceanii generuje średnio $296 \mathrm{~kg}$ SMŻ, a mieszkaniec krajów rozwijających się np. regionu Azji Południowej i Południowo-wschodniej $(126 \mathrm{~kg})$ czy regionu Afryki Subsaharysjkiej $(167 \mathrm{~kg})$ jest odpowiedzialny za dwukrotnie mniejszy tonaż SMŻ (HLPE, 2014). 


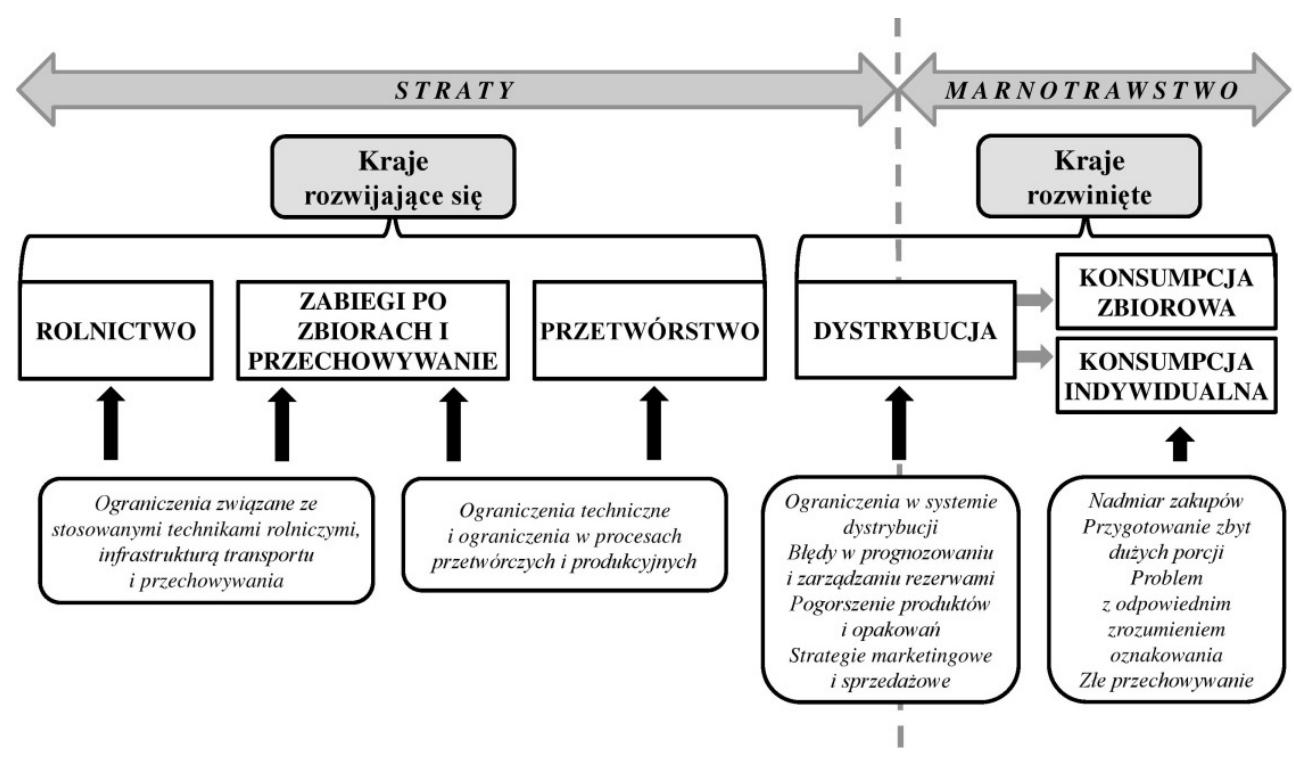

Rys. 1. Czynniki wpływające na powstawanie strat i marnotrawstwa żywności

Fig. 1. Factors influencing the appearance of food losses and waste

Źródło: opracowano na podstawie BCFN (2012), HLPE (2014), FAO (2014).

Straty występują głównie na pierwszych etapach łańcucha rolno-żywnościowego i dotyczą produkcji rolnej, zabiegów pożniwnych, magazynowania, transportu, przetwórstwa i dystrybucji żywności (FAO, 2014). Zarówno w krajach rozwiniętych jak i rozwijających się udział strat i marnotrawstwa żywności w stosunku do produkcji występuje na podobnym poziomie (rys. 2). Jednakże w przypadku krajów rozwijających się w większości dochodzi do strat niżeli do marnotrawstwa żywności np. w krajach regionu Afryki Subsaharyjskiej straty stanowią ponad 95\% ogółu powstających SMŻ. Przyczynami powstawania strat są m.in. ograniczenia techniczne (np. brak odpowiedniej infrastruktury do przechowywania bądź transportu żywności) i ograniczenia technologiczne (np. występowanie nieprawidłowości związanych z przebiegiem procesów przetwórczych) oraz brak fachowej wiedzy związanej $\mathrm{z}$ produkcją rolniczą, przetwórstwem bądź magazynowaniem żywności (Gustavsson i in., 2011; HLPE, 2014). Sytuacja wygląda odwrotnie w krajach rozwiniętych, gdzie udział strat jest niższy. Wynika to m.in. z procesu produkcji żywności, który jest wyspecjalizowany i w zależności od etapu łańcucha rolnożywnościowego przebiega zgodnie $\mathrm{z}$ różnymi obligatoryjnymi bądź dobrowolnymi standardami czy dobrymi praktykami (np. system HACCP, Dobre Praktyki Produkcyjne, Dobre Praktyki Higieniczne, Dobre Praktyki Rolnicze, standardy IFS czy BRC).

Z kolei marnotrawstwo żywności występuje na dalszych etapach łańcucha rolnożywnościowego podczas dystrybucji (np. produkt nie spełnia standardów „kosmetycznych” w sprzedaży detalicznej) i konsumpcji (np. niespożycie żywności zakupionej przez gospodarstwa domowe przed upływem terminu przydatności do spożycia) i charakteryzuje się zmniejszeniem masy jadalnej żywności bez względu na przyczynę (Gustavsson i in., 2011; HLPE, 2014; FAO, 2014). Według szacunków FAO, w krajach Europy, Ameryki Północnej i Oceanii, jeden mieszkaniec marnotrawi od 95 do 115 kg żywności rocznie. 
Inaczej sytuacja wygląda w krajach rozwijających się. W Afryce Subsaharyjskiej i Południowej oraz Azji Południowo-Wschodniej rocznie jeden mieszkaniec marnuje prawie dziesięciokrotnie mniej żywności (6 do $11 \mathrm{~kg} / \mathrm{os} / \mathrm{rok}$ ) (Gustavsson i in., 2011). Marnotrawstwo związane jest głównie $\mathrm{z}$ nieprawidłową dystrybucją, transportem, przechowywaniem żywności oraz nieodpowiednim przygotowaniem na potrzeby konsumpcji w gospodarstwach domowych i zakładach gastronomicznych. Nieprawidłowości te często wynikają z zachowań konsumenckich i łączone są ze świadomą decyzją odpowiedzialną za wyrzucenie żywności (Parfitt i in., 2010).

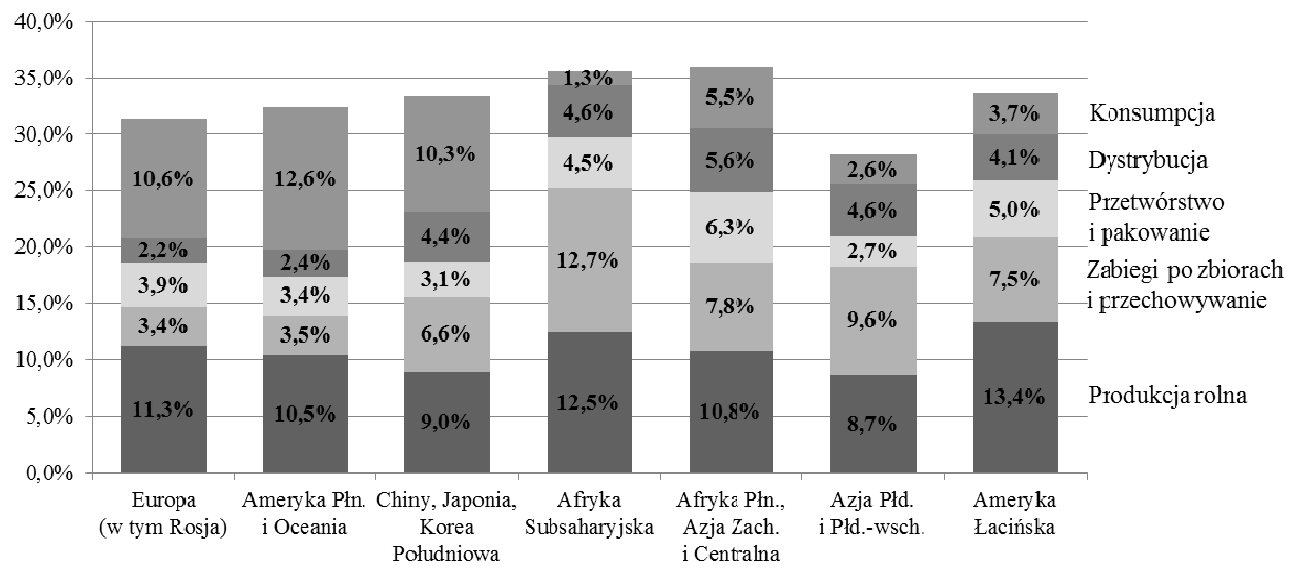

Rys. 2. Straty i marnotrawstwo żywności w różnych regionach świata

Rys. 2. Food loss and waste in the different world regions

Źródło: opracowano na podstawie HLPE (2014), Gustavsson i in. (2011).

Patrząc na SMŻ pod względem wielkości występowania wśród różnych grup żywności ${ }^{5}$, owoce i warzywa, korzenie i bulwy jadalne są tymi grupami produktów gdzie występują największe straty i marnotrawstwo. Dodatkowo trzeba wziąć pod uwagę to, iż poszczególne produkty żywnościowe są bardzo zróżnicowane pod względem zawartości wody i wartości energetycznej. Ich waga nie odzwierciedla ich wartości żywieniowej, dlatego też straty i marnotrawstwo można także wyrażać pod względem jakościowym, czyli utracie wartości energetycznej żywności (kcal) oraz utraty wartościowych odżywczo składników (makro i mikroskładników m.in. białek, witamin czy składników mineralnych) (Lipinski i in., 2013; EIU, 2014; HLPE, 2014). W swych badaniach Lipinski i in. (2013) oszacowali, że 1,3 mld ton żywności rocznie traconej lub marnotrawionej odpowiada pod względem energetycznym ponad 1,5 kwadryliona kalorii. Stanowi to $24 \%$ utratę wszystkich kalorii pochodzących z wyprodukowanej żywności, z czego zboża i produkty zbożowe są odpowiedzialne za ponad połowę utraconych kalorii. Oznacza to, że jedna na cztery kalorie wyprodukowane dla zaspokojenia potrzeb organizmu nie jest mu dostarczana (Kummu i in., 2012; Lipinski i in., 2013).

\footnotetext{
${ }^{5} \mathrm{~W}$ metodologii opracowanej przez J. Gustavsson i in. dla FAO, grupy produktów żywnościowych podzielono na: zboża (bez piwa), warzywa korzeniowe i bulwiaste, nasiona oleiste i rośliny strączkowe (z orzechami), warzywa owoce (z bananami), mięso, ryby i owoce morza, mleko i jaja (Gustavsson i in., 2011).
} 


\section{A. Obiedzińska}

Utracona bądź zmarnowana żywność oznacza także utratę zasobów naturalnych i przyczynia się do zmniejszenia wykorzystania już ograniczonych zasobów naturalnych takich jak woda, ziemia czy paliwa kopalniane (Kummu i in., 2012; FAO, 2013; FAO, 2015). Od dawna wiadomo, że produkcja i konsumpcja żywności wpływa ujemnie na środowisko (Foster i in., 2006; IOM, NRC, 2015). Nierównoważona eksploatacja środowiska naturalnego wynikająca $\mathrm{z}$ uprzemysłowienia rolnictwa może mieć przełożenie na zapewnienie bezpieczeństwa żywnościowego (Buks, Obiedzińska, Prandecki, 2016). Tym bardziej występowanie strat i marnotrawstwa żywności powoduje generowanie podwójnego obciążenia na środowisko. Pierwsze obciążenie wynika $\mathrm{z}$ powodu nakładów poniesionych na produkcję żywności, a drugie z powodu utylizacji powstałych strat $\mathrm{i}$ marnotrawstwa i obejmują m.in. emisję gazów cieplarnianych ${ }^{6}\left(\mathrm{~N}_{2} \mathrm{O}, \mathrm{CH}_{4}, \mathrm{CO}_{2}\right)$, które negatywnie wpływają na środowisko (Garnett, 2011).

Straty i marnotrawstwo żywności przekładają się także na straty ekonomiczne (FAO, 2013, EIU, 2014). Ich wielkość zależny od tego na jakim etapie łańcucha rolnożywnościowego doszło do strat czy marnotrawstwa. Skutki ekonomiczne dotyczą różnych podmiotów ${ }^{7}$ biorących udział $\mathrm{w}$ łańcuchu rolno-żywnościowym i zwiększają się wraz z kolejnym etapem osiagając całkowitą stratę ekonomiczną na etapie konsumpcji, gdzie konsumenci przeznaczają część dochodu na żywność, której nie spożyją i w ostateczności trafi ona do kosza na śmieci jako odpad żywnościowy (HLPE, 2014). W krajach rozwiniętych wartość ekonomiczna jaka jest ponoszona z powodu SMŻ stanowi od 0,5 do $1 \%$ PKB. W krajach rozwijających się, gdzie rynek żywności tworzy od 20-40\% PKB, wartość ponoszonych strat $\mathrm{z}$ tytułu niespożytej żywności może sięgać nawet do 15\% PKB (Sutton i in., 2014). Przykładowo, Nahman i de Lange (2013) oszacowali, że całkowity koszt SMŻ w całym łańcuchu rolno-żywnościowym w Afryce Południowej wyniósł około 7,7 mld USD co stanowi równowartość $2,1 \%$ rocznego produktu krajowego brutto. W ujęciu światowym, generowane straty i marnotrawstwo żywności rocznie obciąża światową gospodarkę na ponad 1 bln USD, a surowce i przetwory należące do grupy warzyw i owoców, zbóż oraz mięsa są za to głównie odpowiedzialne (FAO, 2014). Ponadto, ponoszone są koszty zewnętrzne (tzw. ukryte koszty które nie są brane pod uwagę w analizie kosztów) obejmujące koszty społeczne i środowiskowe. Te pierwsze związane są m.in. z utratą źródła utrzymania czy utratą zdrowia i łącznie wynoszą około 900 mld USD rocznie. Natomiast koszty środowiskowe dotyczą m.in. emisji gazów cieplarnianych zarówno przy produkcji jak i utylizacji żywności czy niedostatku wody i łącznie zostały oszacowane na 700 mld USD rocznie (FAO, 2014).

\section{Straty i marnotrawstwo żywności a bezpieczeństwo żywnościowe}

SMŻ generują wiele negatywnych skutków, które mogą bezpośrednio bądź pośrednio wpływać na 4 filary (wymiary) bezpieczeństwa żywnościowego, czyli na dostępność żywności, dostęp do żywności, wykorzystanie żywności oraz stabilność dostępności i

\footnotetext{
${ }^{6}$ Utracona i zmarnotrawiona żywność odpowiedzialna jest za emisję 4,4 GtCO2 ekw. co stanowi 8\% emisji spowodowanych działalnością człowieka (FAO, 2017a).

${ }_{7}^{7}$ m.in. przedsiębiorstwa przetwórcze, które przeznaczyło zasoby ludzkie, infrastrukturę, surowiec i energię na wyprodukowanie żywności, która nie została sprzedana bądź straty ekonomiczne w wyniku nie użycia surowca, który nie spełnia kryteriów jakościowych do produkcji, bądź odrzucenie produktów żywnościowych, które nie spełniają standardów w handlu detalicznym.
} 
dostępu do żywności $w$ czasie (rys.3). Skutki te mogą być rozpatrywane z perspektywy skutków ekonomicznych, środowiskowych, społecznych bądź zdrowotnych i dotyczyć skali mikro (gospodarstwa domowego, producenta), mezo (łańcucha rolno-żywnościowego) lub makro (kraj, dana społeczność) (Lipinski i in., 2013; Tielens, Candel, 2014; HLPE, 2014). Występowanie marnotrawstwa jest bardziej rozumiane, jako symptom ogólnie zamożniejszych i zabezpieczonych w żywność środowisk, które wykazują nadwyżkę zasobów żywności (EIU, 2014). Dlatego też na bezpieczeństwo żywnościowe większy wpływ będą miały generowane straty żywnościowe. Straty i marnotrawstwo mogą mieć wpływ na zmniejszenie wolumenu wyprodukowanych surowców rolnych, a także produktów przetwórstwa, co może wpływać na zmniejszenie się światowej bądź krajowej dostępności żywności czyli pierwszy filar bezpieczeństwa żywnościowego. Szacuje się, że gdyby zmniejszono o 1/4 ilość generowanych SMŻ pod względem tonażu to można by wyżywić dodatkowo ponad $870 \mathrm{mln}$ osób, czyli o wiele więcej niż liczba osób cierpiących z powodu niedożywienia pod względem energetycznym (FAO, 2017a).

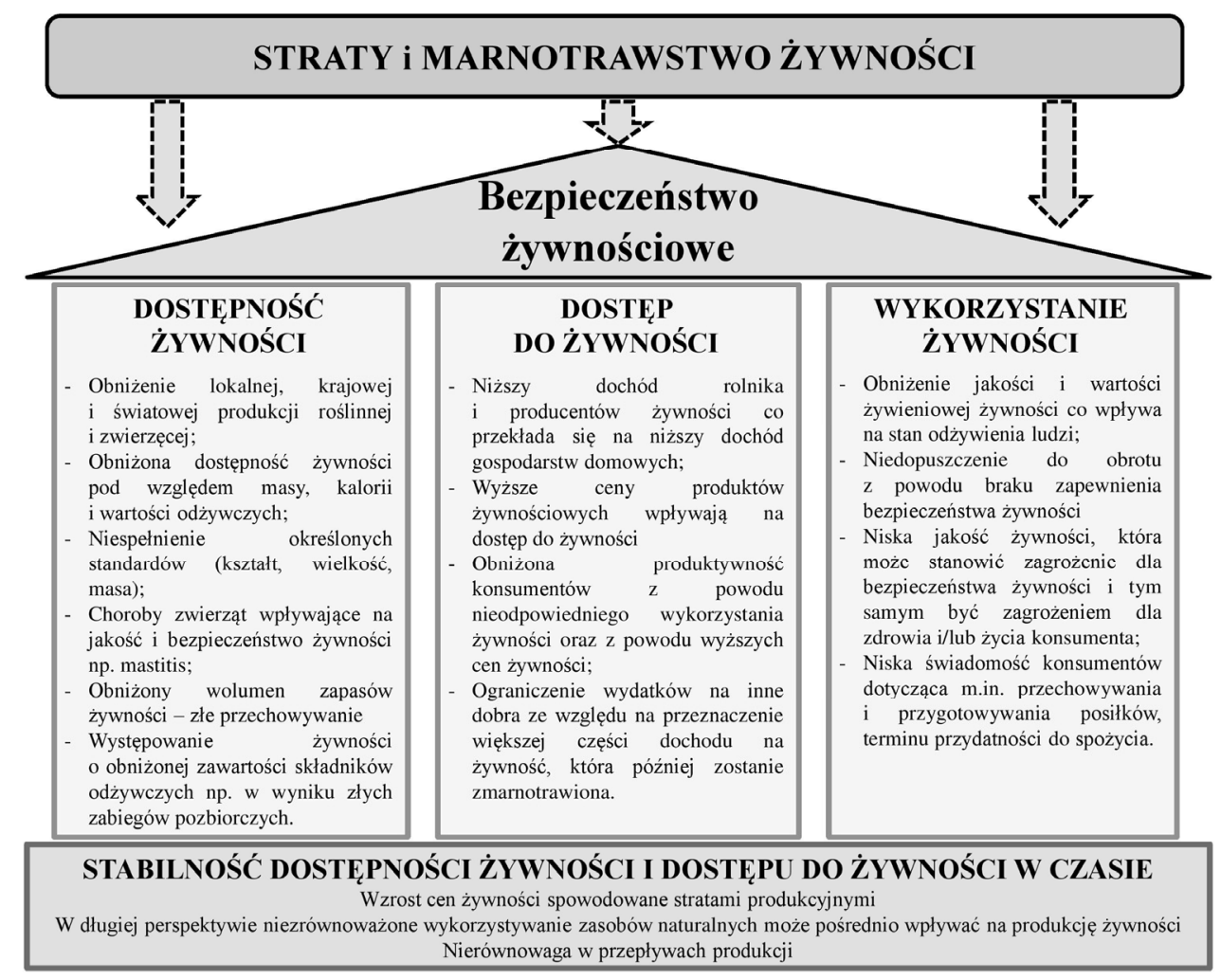

Rys. 3. Wpływ strat i marnotrawstwa żywności na filary bezpieczeństwa żywnościowego

Fig. 3. Food loss and waste impact on food security pillars

Źródło: opracowanie własne na podstawie FAO (2011), Tielens, Candel (2014), HLPE (2014)

Generowane straty żywności (w tym surowców rolnych) bezpośrednio i negatywnie wpływają na dochód gospodarstw rolnych, producentów żywności i konsumentów oraz 


\section{A. Obiedzińska}

oddziałują na wzrost cen żywności i tym samym obniżają możliwość zapewnienia ekonomicznego i fizycznego dostęu do żywności czyli drugiego filaru bezpieczeństwa żywnościowego (Gustavsson i in., 2011; HLPE, 2014). Brak wystarczającej siły nabywczej uniemożliwia gospodarstwom domowym zaspokojenie ich potrzeb żywnościowych. Jednakże obniżając realną cenę żywności i zwiększając popyt na świeżą żywność (nieprzetworzona) wpływa się także na łatwość jej wykorzystania i konsumowanie większych porcji. W konsekwencji oddziałuje to na zwiększenie marnotrawstwa na etapie konsumpcji. Innym problemem obejmującym drugi filar bezpieczeństwa żywnościowego, który w szczególności dotyczy krajów rozwijających się regionów Afryki, Azji i Ameryki Południowej jest brak odpowiedniej infrastruktury łańcucha rolno-żywnościowego, np. łańcucha chłodniczego $\mathrm{w}$ transporcie i przechowywania żywności, co wpływa na powstawanie strat. Z analizy składowych Światowego Indeksu Bezpieczeństwa Żywnościowego $(\mathrm{GFSI})^{8}$ wynika, że straty żywności występujące w danym kraju są ujemnie skorelowane z jej infrastrukturą rolną a także ogólną wartością GFSI (EIU, 2014). Dodatkowo w wielu krajach rozwijających się miejskie i wiejskie gospodarstwa domowe nie tylko przeznaczają ponad $50 \%$ swojego dochodu na żywność, ale także mają ograniczoną możliwość przechowywania jej ze względu na brak odpowiedniego zaplecza np. lodówki. Nieodpowiednie przechowywanie zapasów żywnościowych na poziomie krajowym, surowców rolnych po zbiorze $\mathrm{w}$ gospodarstwach rolnych czy zakupionej żywności na poziomie gospodarstwa domowego może prowadzić do obniżenia ich wartości odżywczej czyli ich jakości żywieniowej (m.in. utrata witamin i składników mineralnych, degradacja tłuszczy), co w konsekwencji może wpływać na zapewnienie odpowiedniego wykorzystania żywności (HLPE, 2014). Dla zapewnienia bezpieczeństwa żywnościowego pod względem żywieniowym, utrata żywności bogatszej w składniki odżywcze jest większą stratą niż utrata żywności, która zawiera niższą zawartość składników odżywczych (Lipinski i in., 2013; EIU, 2014). Dostarczenie odpowiednio zbilansowanej diety, która zaspokajałaby wymagania pod względem makro- i mikroskładników jest jednym z czynników wpływających na dobrostan człowieka (European Commission, 2009). Ponadto złe przechowywanie i nieodpowiednie obchodzenie się z surowcem czy żywnością na każdym etapie łańcucha rolno-żywnościowego może prowadzić do ryzyka wystapienia zagrożenia fizycznego, chemicznego bądź biologicznego. Będzie to miało wpływ na zapewnienie bezpieczeństwa żywności (food safety), które jest składową odpowiedniego wykorzystania żywności wpływając tym samym na zapewnienie bezpieczeństwa żywnościowego (HLPE, 2014; Obiedzińska i in., 2016). Aby chronić konsumentów przed potencjalnymi zagrożeniami mogącymi mieć swoje źródło w spożywanej żywności, w podmiotach biorących udział w łańcuchu rolno-żywnościowym stosuje się różne standardy zapewnienia jakości i bezpieczeństwa żywności. Jednakże mogą one wpływać dwukierunkowo na powstawanie strat i marnotrawstwa żywności. $Z$ jednej strony przestrzeganie wymagań higieniczno-sanitarnych względem bezpieczeństwa żywności minimalizuje ryzyko wprowadzenia do obrotu niebezpiecznej żywności, która mogłaby stanowić zagrożenie dla zdrowia i/lub życia konsumentów. Niestosowanie tych wymagań

\footnotetext{
8 Indeks Global Food Security Index (GFSI), opracowany przez brytyjski ośrodek badawczy Economist Intelligence Unit przy finansowaniu DuPont, opiera się na modelu uwzględniającym ilościowe i jakościowe dane wyrażone w 28 wskaźnikach, pogrupowanych według trzech wymiarów bezpieczeństwa żywnościowego: dostęność żywności, dostęp do żywności oraz jakość i bezpieczeństwo żywności. W wymiarze dostęp do żywności ujęty jest wskaźnik - straty żywności (http://foodsecurityindex.eiu.com/).
} 
sprawia, że żywność ze względów bezpieczeństwa musi zostać odrzucona, co prowadzi do utraty żywności i powstania odpadów, które następnie muszą być zutylizowane (Gustavsson i in., 2011; SDSN, 2013). Z drugiej strony stosowanie standardów kosmetycznych np. dotyczących wybarwienia skórki jabłka czy główki kapusty bądź kształtu marchwi czy ziemniaka, wpływają na wyeliminowanie z rynku produktów pełnowartościowych pod względem odżywczym (Godfray i in., 2010). Obecnie prowadzi się działania w kierunku bardziej liberalnego podejścia odnośnie wymogów kosmetycznych dotyczących żywności, jak np. owoców i warzyw (Komisja Europejska, 2008). W kwestii marnotrawstwa żywności wiele zależy od właściwego gospodarowania żywnością przez konsumentów ostatecznych. Ważna jest nie tylko wiedza na temat przechowywania żywności i przygotowywania posiłków, ale także zwyczaje żywieniowe, które warunkują spożycie żywności. Często, części jadalne żywności nie są spożywane ze względów kulturowych (np. brak spożycia mięsa końskiego czy owadów) bądź religijnych (np. brak spożycia wieprzowiny przez muzułmanów). Z jednej strony występowanie SMŻ świadczy o braku równowagi pomiędzy dostępnością żywności a dostępem do żywności w wymiarze globalnym (HLPE, 2014). Z drugiej strony generowana nadwyżka po stronie produkcji żywności może być uważana za tzw. poduszkę bezpieczeństwa wpływającą na stabilność dostępności żywności i dostępu do żywności. Bez takiego zabezpieczenia ceny żywności byłyby o wiele wyższe co mogłoby wpłynąć na zapewnienie bezpieczeństwa żywnościowego (HLPE, 2014). W perspektywie długookresowej gdzie zwiększająca się populacja wymaga zwiększenia produkcji żywności, obecnie generowane SMŻ mogą wpływać na dostępność zasobów naturalnych ponieważ są tożsame ze stratami nakładów zasobów naturalnych, które zostały nieefektywnie wykorzystane (FAO, 2013; Tielens, Candel, 2014; FAO, 2015). Ponadto, zarówno przy produkcji żywności jak i później podczas utylizacji powstałych strat i marnotrawstwa żywności dochodzi do emisji gazów cieplarnianych. Gazy te wykazują negatywne oddziaływanie na środowisko prowadząc do zmian w ekosystemach i generowania negatywnych efektów zewnętrznych, co w konsekwencji może wpływać na zapewnienie bezpieczeństwa żywnościowego (Buks, Obiedzińska, Prandecki, 2016). Z perspektywy zasobów naturalnych, redukcja SMŻ jest częścią tworzenia zrównoważonych systemów żywnościowych wpływając na zmniejszenie ilości generowanych emisji gazów cieplarnianych, zmniejszenie zapotrzebowania na ziemię, energię i wodę oraz oszczędność nakładów finansowych (Searchinger i in., 2013). Tym samym, zmniejszając straty i marnotrawstwo można się przyczynić do przyszłej dostępności żywności (IOM, NRC, 2011; Searchinger i in., 2013).

\section{Podejmowane działania w kierunku prewencji i wykorzystania strat i marnotrawstwa żywności}

Złożoność systemu żywnościowego zwiększa złożoność problemu związanego ze stratami i marnotrawstwem żywności (Payne, 2014). Dlatego też, istnieje wiele działań czy też podejść, które można wykorzystać do prewencji występowania strat i marnotrawstwa żywności i tym samym przyczynić się bezpośrednio lub pośrednio do zwiększenia bezpieczeństwa żywnościowego (SDSN, 2013; Searchinger i in., 2013; HLPE, 2014). Surowce rolne i żywność, które mogą być potencjalnie utracone lub zmarnowane, można powtórnie wykorzystać przy spełnieniu odpowiednich warunków np. higienicznosanitarnych. Biorąc pod uwagę opracowaną hierarchię mającej na celu odpowiednie 
zarządzanie powstających SMŻ, dwa pierwsze priorytety czyli (1) prewencja strat i marnotrawstwa żywności oraz (2) redystrybucja żywności, moga wpływać w dużym stopniu na bezpieczeństwo żywnościowe (rys. 4).

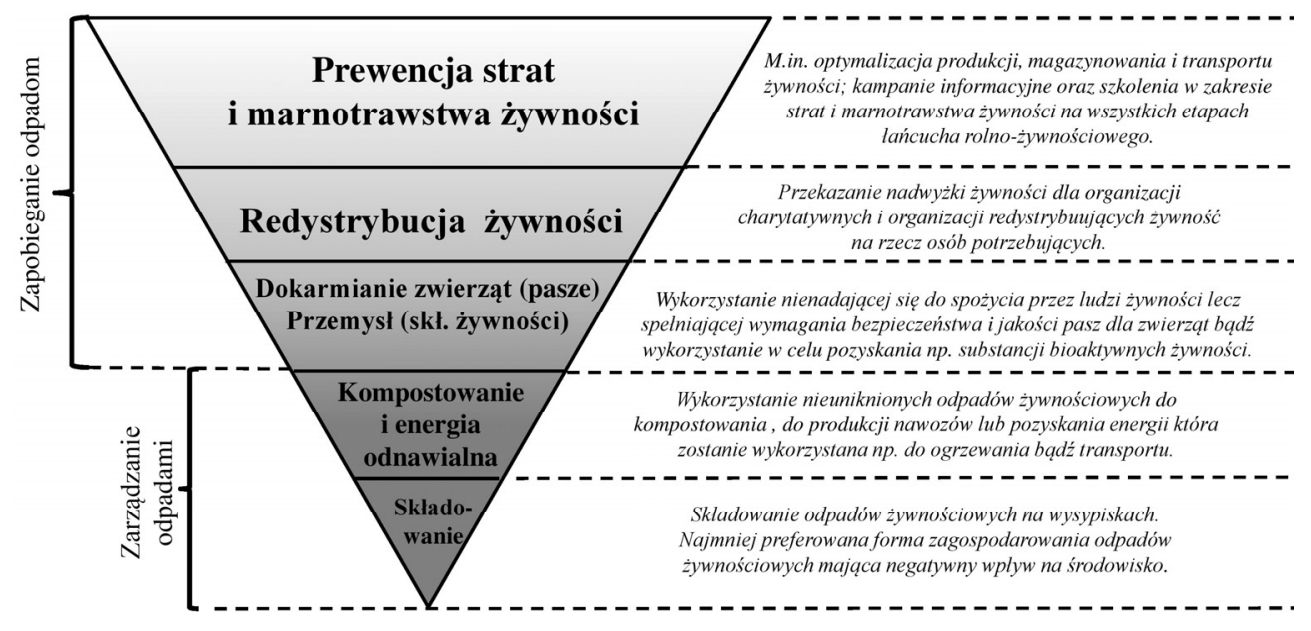

Rys. 4. Zarządzanie stratami i marnotrawstwem żywności

Fig. 4. Food loss and waste management

Źródło: opracowano na podstawie http://feedbackglobal.org/.

Zapobieganie powstawaniu strat i marnotrawstwa żywności na każdym etapie łańcucha rolno-żywnościowego jest najbardziej pożądaną formą postępowania w efektywnie działającym systemie żywnościowym. Działania te powinny być podejmowane w pierwszej kolejności i być odpowiednio dostosowane w zależności od etapu łańcucha rolno-żywnościowego, zaangażowanych uczestników oraz charakteru produktu żywnościowego (HLPE, 2014). Obecnie prowadzonych jest wiele działań i powstaje wiele inicjatyw w kierunku redukcji strat i marnotrawstwa żywności (Lipinski i in., 2013). Przykładowo na poziomie globalnym jest inicjatywa SAVE FOOD, na poziomie Unii Europejskiej funkcjonuje Unijna Platforma dot. Strat i Marnotrawstwa Żywności (EU Platform on Food Losses and Food Waste), a na poziomie krajowym w Polsce od 2011 roku działa Rada ds. Zrównoważonego Wykorzystania Żywności (European Commission, 2016; http://www.save-food.org; http://www.rada.niemarnuje.pl/). Wszystkie wyżej wymienione inicjatywy mają na celu m.in podnosić świadomość na temat wpływu i możliwych rozwiązań dotyczących SMŻ wśród wszystkich aktorów łańcucha rolnożywnościowego czy opracowywać skuteczne polityki, strategie i programy rozwojowe. Pomocą w odpowiednim ukierunkowaniu działań są podejmowane czynności w celu oszacowania SMŻ w łańcuchu rolno-żywnościowym, uwzględniając jego poszczególne etapy. Dla krajów Unii Europejskiej w ramach projektu FUSIONS wypracowano działania w kierunku efektywniejszego wykorzystania zasobów i m.in. opracowano metodologię mierzenia SMŻ oraz oszacowano wolumen SMŻ (Stenmarck i in., 2016; Tostivint i in., 2016). Także na poziomie krajowym prowadzone są badania w celu oszacowania SMŻ powstających w różnych etapach łańcucha rolno-żywnościowego (Wrzosek i in., 2014; Śmiechowska, Chrzanowska, 2015; Seremak-Bulge i in., 2015; Borowski i in., 2016). 
Z praktycznych przykładów prewencji SMŻ jest ograniczenie powstawania strat pożniwnych w krajach rozwijających się, które może zwiększyć dochód gospodarstw rolnych i drobnych przetwórców przyczyniając się do wzrostu dostępu do żywności oraz zwiększyć dostępność żywności dla danej społeczności gdzie działania prewencyjne zostały podjęte (Gustavsson i in., 2011; Tielens, Candel, 2014). Z badań Gitonga, De Groote i Tefera (2015) wynika, że zastosowanie metalowych silosów przez drobne gospodarstwa rolne w Afryce na przykładzie Kenii, może wpłynąć nie tylko na obniżenie niedożywienia wśród osób, ale także może zwiększyć dochód rolników. Wykorzystanie silosów umożliwia przechowywanie i sprzedaż zbiorów po wyższych cenach, gdy popyt przewyższa podaż, a także wpływa korzystnie na jakość surowca. W krajach rozwiniętych znaczny udział w SMŻ stanowi marnotrawstwo, które głównie generowane jest przez konsumentów ostatecznych. Dlatego też prowadzonych jest wiele kampanii społecznych mających na celu uświadomienie konsumentów o ilości marnowanej przez nich żywności oraz zapewnieniu praktycznych wskazówek dotyczących jej przechowywania czy poprawnego zrozumienia znakowania produktów (np. w Unii Europejskiej rozróżnienie terminów przydatności do spożycia „,najlepiej spożyć przed” i ,należy spożyć do”). Dla przykładu, tego typu prowadzone kampanie w latach 2007-2015 w Wielkiej Brytanii wpłynęły na 17\% spadek generowanych odpadów żywnościowych, którym można zapobiec ${ }^{9}$ na poziomie gospodarstwa domowego (WRAP, 2017). Ograniczając straty i marnotrawstwo żywności w danym regionie trzeba także mieć na względzie, jakie będzie oddziaływanie na inne regiony biorące udział m.in. w globalnych systemach żywnościowych. W pracy przygotowanej przez Rutten M., Verma M., Mhlanga N. i Bucatariu C. dla FAO, za pomocą analizy czterech różnych scenariuszy wydarzeń zbadano jak obniżenie ilości powstających SMŻ w Unii Europejskiej może wpłynąc na ceny w Afryce Subsaharyjskiej m.in. ceny artykułów rolno-spożywczych (FAO, LEI, 2015). Wszystkie scenariusze wykazały spadek cen na rynku, ze względu na zakładane zmniejszenie o 50 procent SMŻ w UE. Obniżenie cen z jednej strony będzie korzystne dla Unii Europejskiej (m.in. konsumenci produktów żywnościowych w Unii Europejskiej będą odczuwać korzyść z powodu niższych cen żywności), a z drugiej strony niekorzystne dla Afryki Subsaharyjskiej (m.in. ze względu na to, iż producenci jako sprzedający do UE będą tracić z powodu zwiększonej konkurencji ze strony unijnych producentów żywności) (FAO, LEI, 2015).

Drugim w hierarchii działań w zakresie zarządzania stratami i marnotrawstwem żywności jest redystrybucja żywności zdatnej do spożycia, która w zależności od etapu łańcucha rolno-żywnościowego nie trafiła do obrotu lub została $\mathrm{z}$ niego wycofywana z powodu różnych przyczyn. W przypadku etapu produkcji rolniczej jadalne warzywa bądź zboża mogą zostać niezebrane $\mathrm{z}$ powodu nieopłacalności zbioru bądź niespełnienia kryteriów handlowych, w przypadku dystrybucji żywność może być wycofana z powodu naruszenia opakowania zbiorczego bądź bliskiej daty przekroczenia terminu do spożycia (Lipinski i in., 2013). Na poziomie etapu dystrybucji i konsumpcji, redystrybucją żywności zajmują się organizacje charytatywne, takie jak Banki Żywności, które otrzymując darowizny od sieci sprzedawców i konsumentów przekazują je osobom potrzebującym (Schneider, 2013). Przykładowo w Unii Europejskiej $79 \mathrm{mln}$ osób żyje poniżej progu

\footnotetext{
${ }^{9}$ W systematycznie przeprowadzanych badaniach WRAP (The Waste and Resources Action Programme) na temat marnotrawstwa żywności na poziomie gospodarstwa domowego, w metodologii odpady żywnościowe są podzielone na 3 kategorie: do uniknięcia, możliwe do uniknięcia i niemożliwe do uniknięcia. Odpady żywnościowe do uniknięcia to żywność i napoje, które były jadalne przed wyrzuceniem do śmieci (WRAP, 2017).
} 
ubóstwa, a $16 \mathrm{mln}$ z nich korzysta z pomocy żywnościowej pochodzącej od instytucji charytatywnych (European Parliament, 2011). W Polsce, aby zachęcić i umożliwić producentom przekazywanie żywności, która zostałaby zmarnowana, od 1 października 2013 roku wprowadzono przepisy zwalniające darczyńcę z odprowadzania podatku VAT od darowizny. W okresie od maja 2015 do czerwca 2016 roku Federacja Polskich Banków Żywności przekazała ponad 55 tys. ton żywności, o wartości $175 \mathrm{mln}$ zł, na cele społeczne m.in do jadłodajni, domów dziecka czy rodzin wielodzietnych (FPBŻ, 2016).

W ostateczności jeżeli powstałe SMŻ nie zostały wykorzystane w ramach dystrybucji mogą być wykorzystane np. jako dodatek do pasz w żywieniu zwierzą gdy spełniają wymagania bezpieczeństwa dla pasz. Inną formą zagospodarowania utraconej bądź zmarnowanej żywności jest odzysk składowych żywności bądź pozyskanie cennych substancji bioaktywnych i następnie ich wykorzystanie w produkcji żywności jako dodatki funkcjonalne w różnych produktach (Galanakis, 2012; HLPE, 2014). Przykładami mogą być m.in. wykorzystanie otrąb ryżowych do pozyskiwania oleju ryżowego czy pozyskiwanie serwatki powstającej podczas procesu produkcji serów. Najmniej pożądanym postępowaniem ze stratami i marnotrawstwem żywności jest jej składowanie na wysypiskach, które stanowi duże obciążenie dla środowiska.

\section{Podsumowanie}

Przed obecnie funkcjonującymi systemami żywnościowymi stoi wiele wyzwań gdzie podstawowym jest zapewnienie żywności zarówno dla obecnej populacji jak i stworzenia odpowiednich warunków dla przyszłych pokoleń przy jednoczesnym zmniejszeniu negatywnego oddziaływania na środowisko (SDSN, 2013; HLPE, 2014). Poprawa wydajności łańcucha rolno-żywnościowego poprzez ograniczanie oraz prewencję strat i marnotrawstwa żywności powinna być zadaniem każdego $\mathrm{z}$ krajów, zarówno rozwijających się jak i rozwiniętych w celu zapewnienia bezpieczeństwa żywnościowego. Niniejsze opracowanie pozwala sformułować następujące wnioski:

- straty i marnotrawstwo surowców rolnych i żywności w łańcuchu rolnożywnościowym wpływają na bezpieczeństwo żywnościowe poprzez jego filary: dostęp do żywności, dostępność żywności, wykorzystanie żywności i stabilność dostępu do żywności i dostępności żywności;

- istnieje pilna potrzeba opracowania strategii zharmonizowanych działań w zakresie metodologii szacowania strat i marnotrawstwa żywności, aby móc odpowiednio ukierunkowywać systemowe działania prewencyjne;

- zdefiniowanie krytycznych punktów kontroli występowania strat i marnotrawstwa żywności pozwoli podjąć działania zmierzające do efektywnego wykorzystania zasobów naturalnych, wydajnej i efektywnej produkcji rolno-spożywczej, co przyczyni się do poprawy bezpieczeństwa żywnościowego;

- szczególny nacisk powinien być położony na podniesienie świadomości wśród wszystkich uczestników łańcucha rolno-żywnościowego w zakresie powstających strat i marnotrawstwa żywności. Szkolenia czy kampanie informacyjne powinny być dostosowane dla poszczególnych ogniw lańcucha.

Powyższe wnioski mają charakter ogólny. Ich realizacja powinna być prowadzona przez odpowiednie strategie, które będą dostosowane do specyfiki danego regionu. 
Podejmowane działania wymagają harmonijnej współpracy nie tylko na poziomie regionalnym czy krajowym, ale także $\mathrm{w}$ wymiarze globalnym. W zapewnieniu bezpieczeństwa żywnościowego niezbędne jest holistyczne podejście do zarządzania stratami i marnotrawstwem żywności. Dlatego też w całym łańcuchu rolno-żywnościowym potrzebne jest podejście wielodyscyplinarne, które będzie wymagało zaangażowania nauk technicznych, technologicznych, społecznych, ekonomicznych oraz środowiskowych.

\section{Literatura}

Alexandratos, N., Bruinsma, J. (2012). World agriculture towards 2030/2050: the 2012 revision. ESA Working paper No. 12-03. FAO, Rome.

BCFN (2012). Food waste: causes, impacts and proposals. BCFN, Parma.

Buks, J., Obiedzińska, A., Prandecki, K. (2016). Environmental externalities and food security, Journal of Agribusiness and Rural Development, 2(40), 257-264.

Borowski, M., Kowalewska, M., Kwasek, M., Obiedzińska, A. (2016). Z badań nad rolnictwem społecznie zrównoważonym (37) Analiza strat i marnotrawstwa żywności na świecie i w Polsce (red. M. Kwasek), IERiGŻ-PIB, Warszawa.

Capacci, S., Mazzocchi, M., Shankar, B., Traill, B. (2013). The triple burden of malnutrition in Europe and Central Asia: a multivariate analysis, FAO Regional Office for Europe and Central Asia Policy Studies on Rural Transition No. 2013-7, Rome.

CFS (2012). Coming to terms with terminology. Food Security, Nutrition Security, Food Security and Nutrition, Food and Nutrition Security. Thirty-ninth Session. CFS 2012/39/4. FAO, Rome. Pobrano wrzesień 2016 z: http://www.fao.org/docrep/meeting/026/MD776E.pdf.

EIU (2014). Food Loss and its intersection with food security. The Economist Intelligence Unit Limited.

European Commission (2009). Food security: understanding and meeting the challenge of poverty, Publications Office of the European Union, Belgium.

European Commission (2016). EU Platform on Food Losses and Food Waste. Pobrano marzec 2017 z: https://ec.europa.eu/food/sites/food/files/safety/docs/fw_eu-actions_flw-platform_tor.pdf.

European Parliament (2011). Urgent call to reduce food waste in the EU. Pobrano maj $2016 \mathrm{z}$ : http://www.europarl.europa.eu/news/en/news-room/content/20111121IPR31961/html/Urgent-call-to-reducefood-waste-in-the-EU

FAO (2008). An Introduction to the Basic Concepts of Food Security. FAO, Rome.

FAO (2009). Rome Declaration of the World Summit on Food Security. World Food Summit. 16-18 November 2009, Rome.

FAO (2013). Food wastage footprint: impacts on natural resources. FAO, Rome.

FAO (2014). Definitional framework of food loss, FAO, Rome.

FAO (2015). Food wastage footprint and climate change, FAO, Rome.

FAO (2017a). SAVE FOOD: Global initiative on Food Loss and Waste Reduction, Key Findings. Pobrano styczeń 2017 z: http://www.fao.org/save-food/resources/keyfindings/en.

FAO (2017b). Food wastage footprint \& Climate Change. Pobrano styczeń 2017 z: http://www.fao.org/fileadmin/ templates/nr/sustainability pathways/docs/FWF and climate change.pdf.

FAO, IFAD, WFP (2015). The State of Food Insecurity in the World. Meeting the 2015 international hunger targets: taking stock of uneven progress. FAO, Rome.

FAO, LEI (2015). Potential impacts on sub-Saharan Africa of reducing food loss and waste in the European Union - A focus on food prices and price transmission effects (Rutten M., Verma M., Mhlanga N., Bucatariu C.). FAO, Rome.

FPBŻ (2016). Produkty dla 779101 potrzebujących - podsumowanie Programu Operacyjnego Pomoc Żywnościowa 2014-2020. Pobrano lipiec 2016 z: http://www.bankizywnosci.pl/pl/aktualnosci/produkty-dla779-101-potrzebujacych-podsumowanie-programu-operacyjnego-pomoc-zywnosciowa-2014-2020-br.html.

Foster, C., Green, K., Bleda, M., Dewick, P., Evans, B., Flynn, A., Mylan, J. (2006). Environmental Impacts of Food Production and Consumption: A report to the Department for Environment, Food and Rural Affairs. Manchester Business School. Defra, London.

Galanakis, C.M. (2012). Recovery of high added-value components from food wastes: Conventional, emerging technologies and commercialized applications. Trends in Food Science \& Technology, 26, 68-87. 
Garnett, T. (2011). Where are the best opportunities for reducing greenhouse gas emissions in the food system (including the food chain)?. Food Policy. 36, S23-S32.

Gitonga, Z., De Groote, H., Tefera, T. (2015). Metal silo grain storage technology and household food security in Kenya. Journal of Development and Agricultural Economics. 7(6), 220-230

Godfray, H.Ch.J., Beddington, J.R., Crute, I.R., Haddad, L., Lawrence, D., Muir, J.F., Pretty, J., Robinson, S., Thomas, S.M., Toulmin, C. (2010). Food Security: The Challenge of Feeding 9 Billion People. Science. 327, 812-818.

Gross, R., Schoeneberger, H., Pfeifer, H., Preuss, HJ.A. (2000). The Four Dimensions of Food and Nutrition Security: Definitions and Concepts, FAO, INWENT.

Gustavsson, J., Cederberg, C., Sonesson, U. (2011). Global Food Losses and Food Waste: Extent, Causes and Prevention. FAO, Rome.

HLPE (2014). Food losses and waste in the context of sustainable food systems. A report by the High Level Panel of Experts on Food Security and Nutrition of the Committee on World Food Security, Rome.

http://feedbackglobal.org/. Pobrano: kwiecień 2016.

http://www.save-food.org/. Pobrano: kwiecień 2016

http://www.rada.niemarnuje.pl/. Pobrano: marzec 2017.

http://foodsecurityindex.eiu.com/. Pobrano: marzec 2017.

IFPRI (International Food Policy Research Institute) (2016). Global Nutrition Report 2016: From Promise to Impact: Ending Malnutrition by 2030, Washington DC.

IOM, NRC (2015). A framework for assessing effects of the food system. The National Academies Press, Washington DC

Komisja Europejska (2008). Powrót krzywego ogórka: Komisja pozwoli na sprzedaż „krzywych” owoców i warzyw Pobrano grudzień $2016 \mathrm{z}$ : http://europa.eu/rapid/press-release IP-08-1694_pl.htm.

Kummu, M., de Moel, H., Porkka, M., Siebert, S., Varis, O., Ward, P.J. (2012). Lost food, wasted resources: Global food supply chain losses and their impacts on freshwater, cropland, and fertilizer use. Sci. Total Environ. 438. 477-489.

Lipinski, B., Hanson, C., Lomax, J., Kitinoja, L., Waite, R., Searchinger, T. (2013). Reducing food loss and waste. World Resources Institute, Washington DC.

MacPhail, A.P. (2012). Iron, W: Mann J., Truswell A.S. (eds), Essentials of human nutrition, Oxford University Press, Oxford.

Marzęda-Młynarska, (2014). Globalne zarządzanie bezpieczeństwem żywnościowym na przełomie XX i XXI wieku. Wydawnictwo UMCS, Lublin.

Mejia-Lorio, D.J., Njie, D.N. (2012). The Household Metal Silo: A Helpful Technology for Food Security. FAO, Rome.

Nahman, A., de Lange, W. (2013). Costs of food waste along the value chain: evidence from South Africa, Waste Manag. 33(11), 2493-2500.

Nellemann, C., MacDevette, M., Manders, T., Eickhout, B., Svihus, B., Prins, A.G., Kaltenborn, B.P. (2009). The environmental food crisis - The environment's role in averting future food crises. A UNEP rapid response assessment. United Nations Environment Programme, GRID-Arendal.

Obiedzińska, A., Kwasek, M., Obiedziński, M. (2016). Bezpieczeństwo żywności jednym z filarów bezpieczeństwa żywnościowego. Przeglad Naukowo-Metodyczny. Edukacja dla Bezpieczeństwa, Rok IX Nr 3/2016 (32), 423-439

Parfitt, J., Barthel, M., Macnaughton, S. (2010). Food waste within food supply chains: quantification and potential for change to 2050. Phil. Trans. R. Soc., 365, 3065-3081.

Payne, K.K. (2014). The Consequences of Food Waste. Inquiries Journal/Student Pulse, 6(04). Pobrano listopad 2016 z: http://www.inquiriesjournal.com/a?id=890.

Pinstrup-Andersen, P. (2007). Agricultural research and policy for better health and nutrition in developing countries: a food systems approach. Agricultural Economics, 37, 187-198.

Rutten, M. (2013). What economic theory tells us about the impacts of reducing food losses and/or waste: implications for research, policy and practice. Agriculture \& Food Security, 2 (13). doi:10.1186/2048-7010$2-13$

Schneider, F. (2013). The evolution of food donation with respect to waste prevention. Waste Management, 33, 755-763.

Searchinger, T., Hanson, C., Ranganathan, J., Lipinski, B., Waite, R., Winterbottom, R., Dinshaw, A., Heimlich, R. (2013). Creating a Sustainable Food Future. A menu of solutions to sustainably feed more than 9 billion people by 2050. WRI, Washington DC. 
Seremak-Bulge, J., Grochowska, R., Szczepaniak, I., Szajner, P., Bułkowska, M., Hryszko, K. (2015). Ocena strat ponoszonych na poszczególnych etapach łańcucha mleczarskiego w Polsce (red. R. Grochowska), Studia i Monografie 162, IERiGŻ-PIB, Warszawa.

SDSN (2013). Solutions for Sustainable Agriculture and Food Systems. Pobrano kwiecień 2016 z: http://unsdsn.org/wp-content/uploads/2014/02/130919-TG07-Agriculture-Report-WEB.pdf.

Sutton, M.A., Bleeker, A., Howard, C.M., Bekunda, M., Grizzetti, B., de Vries, W., van Grinsven, H.J.M., Abrol, Y.P., Adhya, T.K., Billen, G.,. Davidson, E.A, Datta, A., Diaz, R., Erisman, J.W., Liu, X.J., Oenema, O., Palm, C., Raghuram, N., Reis, S., Scholz, R.W., Sims, T., Westhoek, H., Zhang, F.S. (2013). Our Nutrient World: The challenge to produce more food and energy with less pollution. CEH, GPNM, INI, Edinburgh.

Stenmarck, A., Jensen, C., Quested, T., Moates, G. (2016). Estimates of European Food Waste Levels, FUSIONS project, IVL Swedish Environmental Research Institute, Stockholm.

Śmiechowska, M., Chrzanowska, B. (2015). Próba określenia przyczyn marnotrawienia żywności w gospodarstwach domowych na przykładzie pieczywa. Rocz. Nauk. Stow. Ekon. Rol. Agrobiz. 17, 2, 237-241.

Thurnham, D.I. (2012). Vitamin A and carotenoids, W: Mann J., Truswell A.S. (eds), Essentials of human nutrition, Oxford University Press, Oxford.

Tielens, J., Candel, J. (2014). Reducing food wastage, improving food security? Food \& Business Knowledge Platform, Hague, Netherlands.

Tostivint, C., O stergren, K., Quested, T., Soethoudt, H., Stenmarck, Å., Svanes, E., O’Connor, C. (2016). Food waste quantification manual to monitor food waste amounts and progression. FUSIONS. BIO by Deloitte, Neuilly-sur-Seine.

Truswell, S. (2012). Protein-energy malnutrition, [In:]: Mann J., Truswell A.S. (eds), Essentials of human nutrition, Oxford University Press, Oxford.

WHO (2016). Pobrano marzec 2017 z: http://www.who.int/features/qa/malnutrition/en.

Włodarek, D., Lange, E., Kozłowska, L., Głąbska, D. (2014). Dietoterapia. Wydawnictwo Lekarskie PZWL, Warszawa.

WRAP (2017). Household Food Waste in the UK 2015. WRAP, London. Pobrano kwiecień 2016 z: http://www.wrap.org.uk/sites/files/wrap/Household food waste in the UK 2015 Report.pdf.

Wrzosek, M., Bilska, B., Kołożyn-Krajewska, D., Krajewski, K., Kondraszuk, A. (2014). Określenie skali i przyczyn strat żywności w handlu detalicznym na przykładzie mleka i jego przetworów, ŻYWNOŚĆ. Nauka. Technologia. Jakość, 2 (93), 225-238. 